\title{
MulawarmanLawReview
}

\section{Penguasaan Tanah Oleh Orang Asing Dalam Perspektif Hak Bangsa}

\author{
Arif Rachman Nur \\ The Alumni of Law Faculty, Hasanuddin University, Indonesia. \\ E-mail: arif.rachmannur94@gmail.com
}

\begin{abstract}
The Indonesians has a close relation with land, water, space and natural resources in the territory, in order of the Nations Right to the highest order in the hierarchy of land tenure. But concurrently with the times, not only the Indonesian needed land and buildings, but also foreigners who working in Indonesia. It is the background of enactment of Government Regulation No. 41 of 1996 replaced by Government Regulation No. 103 of 2015 about Residential Ownership by Foreigner. Nevertheless the Government Regulation is considered not nationalists because mortgaging the Indonesia's territory to foreigner for investment reason. The method used in this research is a normative research with statute approach, historical approach and comparative approach. This research used primary legal sources and secondary legal sources incorporating nonlegal resources collected with literature research. Then the legal sources are qualitatively analyzed and then presented descriptively. The results of the study shows: 1) Housing ownership does not necessarily have an implication on land ownership, because the adoption of the Horizontal Separation Principle does not allow foreigners to own land even though they already have buildings on it. However, the period of Right to Use which is too long to reach 80 years can conflict with the Rights of the Nation; 2) Land tenure restriction by foreigners permanent residence in Indonesia is an obligation for the government to respect and protect the Rights of the Nation. The land tenure restriction is carried out by limiting housing ownership in the elaboration of subjects, quota restrictions, zoning, arrangements related to buying and selling and the establishment of duties to supervise the ownership of residential houses for foreigners domiciled in Indonesia.
\end{abstract}

Keywords: Nation Rights; Land Ownership by Foreigner; Foreigner Domiciled in Indonesia.

\section{ABSTRAK}

Bangsa Indonesia memiliki hubungan yang erat dengan bumi, air, ruang angkasa dan kekayaan alam yang terkandung di dalamnya, sehingga dalam hierarki penguasaan tanah di Indonesia menempatkan Hak Bangsa pada urutan tertinggi. Akan tetapi seiiring perkembangan zaman, bukan hanya bangsa Indonesia yang membutuhkan tanah dan bangunan, namun juga orang asing yang bekerja di Indonesia. Hal ini kemudian yang melatarbelakangi diundangkannya Peraturan Pemerintah Nomor 41 Tahun 1996 yang diganti dengan Peraturan Pemerintah Nomor 103 Tahun 2015 tentang Pemilikan Rumah Tempat Tinggal atau Hunian oleh Orang Asing yang Berkedudukan di Indonesia. Akan tetapi regulasi tersebut dinilai kurang nasionalis karena menjual wilayah Indonesia kepada asing demi investasi. Tujuan dari penelitian ini adalah untuk mengetahui kedudukan Hak Bangsa dalam hukum tanah Indonesia serta untuk mengetahui penguasaan tanah oleh orang asing setelah berlakunya Peraturan Pemerintah Nomor 103 Tahun 2015 dalam perspektif Hak Bangsa. Adapun metode yang digunakan dalam penelitian ini adalah penelitian normatif dengan pendekatan peraturan perundang-undangan dan pendekatan sejarah. Penelitian ini menggunakan bahan hukum primer dan bahan hukum sekunder yang dilengkapi 
bahan nonhukum yang dikumpulkan melalui studi literatur. Kemudian bahan hukum tersebut di analisis secara kualitatif dan disajikan secara deskriptif. Hasil penelitian menunjukkan bahwa pemilikan rumah tempat tinggal tidak serta merta berimplikasi pada pemilikan tanah, sebab dianutnya Asas Pemisahan Horizontal yang tidak memungkinkan orang asing untuk memiliki tanah meskipun telah memiliki bangunan di atasnya. Meskipun demikian, jangka waktu Hak Pakai yang terlampau lama hingga mencapai 80 tahun dapat berbenturan dengan Hak Bangsa; Pembatasan penguasaan tanah oleh orang asing yang berkedudukan di Indonesia merupakan kewajiban bagi pemerintah dalam menghormati dan melindungi Hak Bangsa. Pembatasan penguasaan tanah tersebut dilakukan dengan pembatasan pemilikan rumah tempat tinggal dalam penjabaran subjek, pembatasan kuota, zonasi dan pengaturan terkait sewa-menyewa.

Keywords: Hak Bangsa; Penguasaan Tanah oleh Orang Asing; dan Orang Asing yang Berkedudukan di Indonesia

Citation: Nur, Arif Rachman, "Penguasaan Tanah Oleh Orang Asing di Indonesia dalam Perspektif Hak Bangsa." Mulawarman Law Review 3 no. 1 (2018): 66-88

\section{INTRODUCTION}

Bangsa Indonesia memiliki hubungan yang erat dengan bumi, air, ruang angkasa dan kekayaan alam yang terkandung di dalamnya, sehingga dalam hierarki penguasaan tanah di Indonesia menempatkan Hak Bangsa pada urutan tertinggi. Dalam Pasal 1 Undang-Undang Nomor 5 Tahun 1960 tentang Peraturan Dasar Pokok-Pokok Agraria (UUPA) disebutkan sebagai hak yang bersifat abadi yang tidak dapat dipisahkan. Hal tersebut tidak bisa dipisahkan dari tanah yang mempunyai dimensi ekonomi, sosial, kultural, politik dan ekologis memiliki kedudukan yang istimewa yang ada sejak sebelum Negara Kesatuan Republik Indonesia diproklamasikan.

Seiring perkembangan zaman, bukan hanya bangsa Indonesia yang membutuhkan tanah dan bangunan, namun juga pihak asing yang berkedudukan di Indonesia. Untuk mengakomodir kebutuhan tersebut, maka dibentuk Undang-Undang Nomor 1 Tahun 1967 tentang Penanaman Modal Asing (UUPMA) yang memberikan kemudahan dalam pemakaian tanah oleh perusahaan modal asing melalui Hak Guna Bangunan, Hak Guna Usaha dan Hak Pakai menurut peraturan yang berlaku, yaitu UUPA. Ketentuan tersebut menjadi pintu masuk bagi penanaman modal asing di Indonesia yang membawa efek domino bagi industri lain di Indonesia. Para investor asing yang masuk ke Indonesia tentu saja membawa pekerja dari negara asal investor. Mau tidak mau, perusahaan harus menyediakan hunian bagi pekerja dan keluarga yang dibawa. ${ }^{1} \mathrm{Hal}$ ini tidak dapat dihindarkan sebab tempat tinggal merupakan HAM yang juga dijamin dalam UUD NRI 1945 dan Universal Declaration of Human Rights. Akan tetapi, tempat

${ }^{1}$ Eko Adiwaluyo, "Kepemilikan Asing di Properti Nasionalisme Vs Iklim Investasi” Diakses dari http://marketeers.com/article/kepemilikan-asing-di-properti-nasionalisme-vs-iklim-investasi.html, Diakses pada 1 Agustus 2018. 
tinggal tersebut bukan hanya kebutuhan bagi WNI semata, melainkan juga orang asing. Fenomena global ini merupakan suatu hal yang tidak dapat dihindari dalam menciptakan bertumbuhan dan pembangunan ekonomi nasional.

Merespon kebutuhan tersebut, maka Pemerintah mengundangkan Peraturan Pemerintah Nomor 41 Tahun 1996 yang diganti dengan Peraturan Pemerintah Nomor 103 Tahun 2015 tentang Pemilikan Rumah Tempat Tinggal atau Hunian oleh Orang Asing yang Berkedudukan di Indonesia (PP Hunian Orang Asing). Pada umumnya pemberian rumah tempat tinggal kepada orang asing tersebut digunakan sebagai sarana untuk memperlancar investasi maupun usaha, yang diharapkan mampu memberikan dampak positif terhadap perekonomian nasional. Akan tetapi PP tersebut dinilai kurang nasionalis karena menjual wilayah Indonesia kepada asing dengan dalih investasi.

Biarpun ditujukan untuk memberikan kepastian hukum kepada orang asing dalam memperoleh tempat tinggal di Indonesia dan mempercepat pertumbuhan ekonomi Indonesia, PP Hunian Orang Asing dinilai kontraproduktif terhadap agenda reforma agraria yang menjadi salah satu pilar UUPA. Hal ini dikarenakan jangka waktu pemilikan rumah tempat tinggal atau hunian yang lebih lama dengan berbagai peraturan perundang-undangan lainnya serta tidak adanya batasan mengenai luasan tanah yang dikuasai. Kemudahan terhadap orang asing dalam memperoleh rumah tempat tinggal atau hunian di Indonesia, satu sisi merupakan suatu diskriminasi terhadap WNI yang juga berhak terhadap tanah. Hal ini juga di dukung dengan laporan Bank Dunia pada tahun 2015 yang menyatakan konsentrasi kekayaan, termasuk tanah, yang dimiliki oleh elit merupakan salah satu penyebab ketimpangan ekonomi di Indonesia. ${ }^{2}$

Adanya kemudahan untuk orang asing dalam memperoleh suatu rumah tinggal atau hunian dan tumpang tindihnya regulasi terkait hal tersebut mengindikasikan adanya diskriminasi terhadap Hak Bangsa sebagai hak penguasaan tanah yang paling tinggi, tujuan dari penelitian ini adalah Untuk mengetahui ketentuan pemilikan rumah tempat tinggal oleh orang asing dalam peraturan perundang-undangan di Indonesia serta kaitannya dengan Hak Bangsa; serta mengetahui pembatasan penguasaan tanah oleh orang asing yang berkedudukan di Indonesia.

\section{METHOD}

Penelitian ini merupakan penelitian hukum normatif yang menggunakan pendekatan perundang-undangan (statute approach), pendekatan sejarah (historical approach)

2 World Bank, "Indonesia Rising Divide" Diakses dari http://www.worldbank.org/en/news/ feature/2015/12/08/indonesia-rising-divide, Diakses pada 1 Agustus 2018. 
dan pendekatan perbandingan (comparative approach). Pengumpulan bahan hukum menggunakan studi kepustakaan (literature research). Bahan hukum yang digunakan adalah bahan hukum primer, antara lain sekumpulan peraturan perundang-undangan dan putusan Mahkamah Konstitusi serta bahan hukum sekunder, antara lain buku hukum, jurnal hukum, surat kabar, dan hasil karya ilmiah.

\section{DISCUSSION}

Penguasaan Tanah Oleh Orang Asing dalam Berbagai Peraturan Perundangundangan di Indonesia serta Kaitannya dengan Hak Bangsa

Subjek yang diatur dalam PP Hunian Orang Asing tidak mencakup seluruh orang asing, melainkan memberikan batasan pada orang asing yang berkedudukan di Indonesia. Pasal 1 PP Hunian Orang Asing mendefinisikan orang asing yang berkedudukan di Indonesia sebagai orang yang bukan WNI yang keberadaanya memberikan manfaat, melakukan usaha, bekerja, atau berinvestasi di Indonesia. Definisi tersebut mengalami perluasan dari definisi sebelumnya yang diatur dalam PP Hunian Orang Asing 1996, yang mengartikan orang asing yang berkedudukan di Indonesia adalah orang asing yang kehadirannya di Indonesia memberikan manfaat bagi pembangunan nasional. Definisi tersebut kemudian diperjelas dalam Peraturan Menteri Agraria/Kepala BPN No. 7 Tahun 1996 tentang Persyaratan Pemilikan Rumah Tempat Tinggal atau Hunian oleh Orang Asing yang menegaskan bahwa definisi tersebut merujuk kepada orang asing yang memiliki dan memelihara kepentingan ekonomi di Indonesia dengan melaksanakan investasi untuk memiliki rumah tempat tinggal atau hunian di Indonesia. Sebelumnya, orang asing yang berkedudukan di Indonesia juga dimuat dalam Pasal PP No. 40/1996 sebagai subjek dari Hak Pakai. Dalam penjelasan Pasal 39 PP No. 40/1996 tersebut dinyatakan bahwa orang asing yang berkedudukan di Indonesia adalah orang asing yang kehadirannya di Indonesia memberikan manfaat bagi pembangunan nasional. Ketiga definisi tersebut mempunyai kesamaan yang tidak berubah dalam menentukan orang asing yang berkedudukan di Indonesia, yaitu orang bukan WNI yang berkontribusi terhadap pembangunan ekonomi nasional.

Definisi yang terdapat dalam PP Hunian Orang Asing dapat dilihat bahwa ada dua kriteria yang digunakan untuk menentukan orang asing yang berkedudukan di Indonesia, yaitu bukan WNI dan memberikan manfaat, melakukan usaha, bekerja atau berinvestasi di Indonesia. Walaupun demikian, definisi tersebut terlampau luas. Hal tersebut dikarenakan dalam mendefinisikan orang asing yang berkedudukan di Indonesia, digunakannya kata "atau" yang menunjukkan sifat alternatif dalam memenuhi kriteria tersebut. 
Pengertian orang asing yang berkedudukan di Indonesia tersebut memberikan celah untuk dimultitafsirkan. Sebab dalam pengertian tersebut terdapat beberapa alternatif yang berbeda satu dengan lainnya dan tiap kriteria memiliki parameter yang berbeda pula. Jika tetap multitasir dan tidak memiliki parameter yang pasti, maka definisi tersebut sesungguhnya tidak berubah sama sekali dengan definisi dalam PP Hunian Orang Asing 1996. Semestinya definisi tersebut bersifat final dan tidak multitafsir. Hal tersebut juga tidak diperjelas dalam bagian penjelasan PP Hunian Orang Asing ataupun peraturan di bawahnya. Bahkan pada masa Orde Baru, dengan hanya memiliki catatan pernah masuk ke Indonesia pada paspornya, orang asing dimungkinkan menguasai tanah dengan Hak Pakai. ${ }^{3}$ Berikut penulis mencoba menguraikan kriteria yang berada dalam definisi orang asing yang berkedudukan di Indonesia:

1) Bukan Warga Negara Indonesia (WNI)

Bukan WNI dalam hal ini adalah individu (naturlijke persoon), bukan badan hukum (recht persoon). Individu dalam hal ini tentu harus memenuhi kriteria cakap secara hukum. Bukan WNI merupakan kriterium mutlak dalam pendefinisian orang asing yang berkedudukan di Indonesia sebagai subjek pemilik hak atas tanah. Hal ini dikarenakan dianutnya Asas Nasionalitas dalam Pasal 9 UUPA yang mengatur hanya WNI yang dapat memiliki hubungan penuh dengan bumi, air dan ruang angkasa dalam wilayah Indonesia. Ketentuan tersebut dimaksudkan agar terjaganya kepentingan politik, pertahanan dan keamanan nasional sebagai satu kesatuan wilayah yang tidak dapat dipecah belah. Asas Nasionalitas tersebut bersumber pada Hak Bangsa yang merupakan hak penguasaan atas tanah tertinggi yang turut menjamin hanya bangsa Indonesia yang memiliki hubungan penuh dengan wilayah Indonesia. Penerapan Asas Nasionalitas tersebut bukanlah suatu tindakan diskriminatif terhadap orang asing, sebab kepentingan nasionallah yang menjadi hal utama. Sehingga Indonesia tetap berdaulat atas wilayahnya dan tidak mengorbankan wilayahnya untuk kepentingan orang asing dalam rangka pertumbuhan ekonomi semata.

Hal lain yang perlu diperhatikan adalah orang asing tersebut berkedudukan di wilayah Indonesia serta dalam jangka waktu tertentu. Berkedudukan dalam pengertian ini berbeda dengan pengertian domisili. Berkedudukan merujuk kepada bertempat tinggal untuk beberapa waktu tertentu tanpa disertai niatan untuk menetap, sedangkan domisili merujuk kepada tempat tinggal asli yang ditandai dengan kehadiran fisik dengan niat untuk menetap dan memiliki hubungan hukum dengan pemiliknya. Namun apabila bukan WNI tersebut malah berdomisili di Indonesia, hal itu malah lebih baik.

${ }^{3}$ Mohammad Hatta, "Hukum Tanah Nasional Dalam Perspektif Negara Kesatuan", Media Abadi, Yogyakarta, 2005, hlm. 132. 
2) Memberikan Manfaat bagi Indonesia

Untuk berhak mendapatkan rumah tempat tinggal atau Sarusun, orang asing yang berkedudukan di Indonesia keberadaannya haruslah memberikan manfaat terhadap Indonesia. Jika merujuk pada penjelasan umum ataupun koseideran PP Hunian Orang Asing, memberikan manfaat dalam hal ini adalah memberikan manfaat dalam bidang perekonomian Indonesia, selain bekerja, mempunyai atau melakukan usaha ataupun berinvestasi di Indonesia. Hal ini dikarenakan terbitnya PP Hunian Orang Asing membawa semangat pertumbuhan ekonomi. ${ }^{4} \mathrm{Hal}$ tersebut juga didukung dengan dikeluarkannya Peraturan Menteri Agraria dan Tata Ruang/Kepala Badan Pertanahan Nasional Nomor 13 Tahun 2016 tentang Tata Cara Pemberian, Pelepasan atau Pengalihan Hak atas Pemilikan Rumah Tempat Tinggal atau Hunian oleh Orang Asing yang Berkedudukan di Indonesia yang menentukan harga minimal pembelian rumah tunggal dan Sarusun yang relatif tinggi. ${ }^{5}$ Akan tetapi menurut penulis, memberikan manfaat bagi pertumbuhan ekonomi Indonesia ini seharusnya juga termasuk orang yang memiliki kualifikasi profesional atau lainnya atau pengalaman yang memiliki nilai atau manfaat atau pengetahuan khusus yang diperlukan bagi Indonesia. Lebih lanjut hal ini akan diuraikan pada tabel 3.

3) Mempunyai atau Melakukan Usaha di Indonesia

Selain memberikan manfaat dibidang perekonomian, bukan WNI untuk dapat disebut sebagai orang asing yang berkedudukan di Indonesia tersebut dapat pula mempunyai atau melakukan usaha di Indonesia. Bidang usaha yang dijalankan bukan WNI tersebut bukan merupakan termasuk ke dalam jenis Usaha Mikro, Kecil dan Menengah (selanjutnya disingkat UMKM), melainkan usaha besar. Dalam hal ini usaha besar merupakan usaha ekonomi produktif yang dilakukan oleh badan usaha dengan jumlah kekayaan bersih atau hasil penjualan tahunan lebih besar dari usaha menengah, yang meliputi usaha nasional milik negara atau swasta, usaha patungan dan usaha asing yang melakukan kegiatan ekonomi di Indonesia. ${ }^{6}$

Bidang usaha yang dijalankan oleh bukan WNI tersebut bukanlah bidang usaha yang tertutup untuk penanaman modal, seperti bidang pertanian untuk budidaya ganja, bidang pariwisata dan ekonomi kreatif untuk perjudian/kasino dan bidang perhubungan dalam hal penyelenggaraan pengujian tipe kendaraan bermotor

\footnotetext{
${ }^{4}$ Lihat Penjelasan Umum Peraturan Pemerintah Nomor 103 Tahun 2015 tentang Pemilikan Rumah Tempat Tinggal atau Hunian Bagi Orang Asing yang Berkedudukan di Indonesia.

${ }^{5}$ Lihat Lampiran Peraturan Menteri Agraria dan Tata Ruang/Kepala Badan Pertanahan Nasional Nomor 13 Tahun 2016 tentang Tata Cara Pemberian, Pelepasan atau Pengalihan Hak atas Pemilikan Rumah Tempat Tingga atau Hunian oleh Orang Asing yang Berkedudukan di Indonesia.

${ }^{6}$ Pasal 1 Undang-Undang Nomor 20 Tahun 2008 tentang Usaha Mikro, Kecil dan Menengah.
} 
serta bidang usaha lain yang ditetapkan oleh pemerintan dan bidang usaha yang terbuka dengan persyaratan, misalnya bidang energi dan sumber daya mineral, bidang perbankan dan bidang tenaga kerja dan transmigrasi. Saat ini bidangbidang tersebut diatur dalam Peraturan Presiden Nomor 39 Tahun 2014 tentang Daftar Bidang Usaha yang Tertutup dan Bidang Usaha yang Terbuka dengan Persyaratan di Bidang Penanaman Modal. Selain itu, ketika memiliki rumah tempat tinggal, berbentuk rumah tunggal ataupun Sarusun, rumah tersebut hanya diperuntukkan sebagai rumah tempat tinggal bukan sebagai fasilitas tambahan bagi bukan WNI untuk menjalankan usahanya.

4) Bekerja di Indonesia

Bukan WNI haruslah memiliki pekerjaan yang jelas dan tetap ketika berada di Indonesia. Pekerjaan tersebut bukanlah bersifat sementara yang dapat diselesaikan dalam waktu singkat dan tidak dapat diperpanjang. Begitupun dengan jenis usaha jasa impresariat yang berhubungan di bidang seni dan olahraga yang bersifat sementara serta pekerjaan yang bersifat darurat. Bukan WNI tersebut datang ke Indonesia bukan untuk mencari pekerjaan. Sehingga ketika datang ke Indonesia, bukan WNI tersebut haruslah memiliki Rencana Penggunaan Tenaga Kerja Asing (selanjutnya disingkat RPTKA). Hal tersebut diperlukan agar nantinya orang asing tersebut bukan malah menjadi beban bagi Indonesia namun dapat memberikan keuntungan lain bagi Indonesia.

5) Berinvestasi di Indonesia

Berinvestasi di Indonesia dalam hal ini adalah dengan melakukan penanaman modal asing secara langsung dengan cara membeli langsung (tanpa lewat pasar modal) saham perusahaan nasional atau mendirikan perusahaan baru, baik lewat BKMP maupun lewat departemen lain. Dalam kaitannya dengan Pasal 5 ayat (2) UUPM, yang menetapkan bahwa penanaman modal asing wajib dalam bentuk PT berdasarkan hukum Indonesia dan berkedudukan di dalam wilayah Indonesia.

Penanaman modal tersebut juga bukan termasuk bidang usaha yang tertutup untuk penanaman modal, seperti bidang pertanian untuk budidaya ganja, bidang pariwisata dan ekonomi kreatif untuk perjudian/kasino dan bidang perhubungan dalam hal penyelenggaraan pengujian tipe kendaraan bermotor serta bidang usaha lain yang ditetapkan oleh pemerintan dan bidang usaha yang terbuka dengan persyaratan, misalnya bidang energi dan sumber daya mineral, bidang perbankan dan bidang tenaga kerja dan transmigrasi. Saat ini bidang-bidang tersebut diatur dalam Peraturan Presiden Nomor 39 Tahun 2014 tentang Daftar Bidang Usaha yang Tertutup dan Bidang Usaha yang Terbuka dengan Persyaratan di Bidang Penanaman Modal. 
Selain menanamkan modalnya di Indonesia, bukan WNI tersebut harus berada atau akan berada di Indonesia dalam waktu relatif lama. Sebab dengan tidak berkedudukan di Indonesia, maka investor tersebut dinilai belum layak tidak mendapatkan hak untuk memiliki rumah tempat tinggal di Indonesia karena tidak terpenuhinya kriteria "berkedudukan di Indonesia" yang telah diurai dalam pembahasan tentang "Bukan Warga Negara Indonesia" diatas.

Dengan demikian, dalam menentukan apakan seseorang merupakan orang asing yang berkedudukan di Indonesia terdiri atas dua kriteria, yaitu: (a) Bukan Warga Negara Indonesia yang memiliki Izin Tinggal di Indonesia; dan (b) Memberikan Manfaat bagi Indonesia; atau (c) Mempunyai atau menjalankan usaha di Indonesia; atau (d) Bekerja di Indonesia; atau (e) Berinvestasi di Indonesia.

Secara historis, larangan pengasingan tanah atau grondververemdings-verbood bukanlah hal baru di Indonesia. Hal tersebut sebelumnya pernah diatur dalam Staatsblad van Nederlandsch-Indie 1875 No. 179 (selanjutnya disingkat S. 1875 No. 179), yang mengatur tentang larangan pengasingan tanah. Dari regulasi tersebut, terdapat pembedaan perlakuan antarsesama pribumi. Hal tersebut dikarenakan pengasingan tanah S. 1875 No. 179 menitiberatkan kepada pembagian golongan, bukannya atas prinsip kewarganegaraan atau nationaliteit seperti yang digunaan dalam UUPA.

Berbeda dengan S. 1875 No. 179, UUPA mengedepankan prinsip kewarganegaan dalam menentukan pengasingan tanah. Pasal 1 UUPA merupakan pasal yang secara terang menjelaskan bahwa adanya hubungan antara bangsa Indonesia dengan seluruh wilayah Indonesia yang merupakan satu kesatuan utuh, bersifat abadi yang dengan kata lain tidak ada suatu kekuasaan yang dapat memutuskan atau meniadakan hubunga tersebut serta menjadi induk dari hak penguasaan atas tanah yang lain. Selain bersifat komunal, Hak Bangsa juga bersiftat religius karena tanah merupakan karunia Tuhan YME. Dengan demikian, maka dapat dipahami bahwa sifat komunalistik mewakili hubungan sosial antara manusia dengan tanah, sedangkan sifat religius mewakili hubungan spiritual manusia dengan tanah, dan sifat abadi mewakili hubungan emosional manusia dengan tanah. ${ }^{7}$ Biarpun demikian, hubungan bangsa Indonesia dengan wilayahnya tersebut merupakan hubungan "kepunyaan", bukan "kepemilikan". 8 Mengingat hubungan tersebut bersifat utuh dan abadi, maka tidak diperkenankan usaha-usaha untuk memecah belah wilayah NKRI.

\footnotetext{
7 Urip Santoso, "Hukum Agraria: Kajian Komperhensif", Kencana, Jakarta, 2012, hlm. 78, Dikutip dari Muhammad Ilham Arisaputra, "Reforma Agraria di Indonesia", Sinar Grafika, Jakarta, (2015): 80.

${ }^{8}$ Efendi Perangin, "401 Pertanyaan dan Jawaban Tentang Hukum Agraria", Raja Grafindo Persada, Jakarta, (1994): 193.
} 
Berdasarkan atas pemikiran konsepsi Hak Bangsa tersebut, maka hanya WNI yang diperkenankan memiliki hubungan penuh dengan wilayah Indonesia, sedangkan orang asing tidak diperbolehkan. Pasal 9 Jo. Pasal 21 UUPA mengandung Asas Nasionalitas juga sejalan dengan Hak Bangsa tersebut. Asas Nasionalitas yang menghendaki hanya WNI yang memiliki hubungan penuh dengan tanah dan sumber daya alam lainnya di Indonesia bukanlah suatu tindakan diskriminatif karena dalam hal apapun bangsa Indonesia harus menjadi tuan rumah di rumah sendiri dan tidak perlu mengorbankan kepentingan nasional demi menyenangkan orang lain atau untuk membujuk penanaman modal asing. ${ }^{9}$

Dalam PP Hunian Orang Asing, orang asing yang berkedudukan di Indonesia diperbolehkan memiliki rumah tunggal unit baru dengan Hak Pakai di atas tanah Hak Pakai atas tanah negara, Hak Pengelolaan atas tanah negara atau Hak Pakai di atas Hak Milik yang dikuasai berdasarkan perjanjian. Selain rumah tunggal, orang asing yang berkedudukan di Indonesia juga dapat memiliki Sarusun dengan Hak Milik pada dibidang tanah Hak Pakai atas tanah negara atau Hak Pengelolaan. Hak Pakai atas rumah tunggal tersebut diberikan untuk jangka waktu 30 tahun yang dapat diperpanjang untuk jangka waktu 20 tahun serta dapat diperbarui untuk jangka waktu 30 tahun. Dengan demikian, Hak Pakai atas rumah tunggal tersebut paling lama dimiliki selama 80 tahun.

Jika dibandingkan jangka waktu Hak Pakai antara PP Hunian Orang Asing dengan PP No. 40/1996 dan PP Hunian Orang Asing 1996, maka akan terlihat seperti tabel berikut:

\section{Tabel 1: Perbandingan Jangka Waktu Hak Pakai untuk Orang Asing yang Berkedudukan di Indonesia}

\begin{tabular}{lcccc}
\hline \multirow{2}{*}{ Regulasi } & \multicolumn{5}{c}{ Jangka Waktu (Tahun) } \\
\cline { 2 - 5 } & Pertama & Perpanjang & Pembaruan & Total \\
\hline PP 40/1996 & 25 & 20 & 25 & 70 \\
\hline PP 41/1996 & 25 & - & 25 & 50 \\
\hline PP 103/2015 & 30 & 20 & 30 & 80 \\
\hline
\end{tabular}

Sumber: Bahan hukum primer, diolah tahun 2018

Dari tabel tersebut, terlihat jika pemberian Hak Pakai dengan jangka waktu paling lama adalah PP Hunian Orang Asing. Ketentuan tersebut meningkat 30 tahun dari ketentuan sebelumnya. Sedangkan jika dibandingkan dengan PP No. 40/1996, jangka waktu dalam PP Hunian Orang Asing juga tetap lebih tinggi. Dengan total jangka waktu selama 80 tahun itu dapat mencakup dua sampai tiga generasi. Biarpun terhitung

${ }^{9}$ A.P. Parlindungan, "Landreform di Indonesia Suatu Studi Perbandingan", Mandar Maju, Bandung, (1991) : 57. 
sangat lama, ketentuan 80 tahun tersebut diberikan secara bertahap karena adanya proses eveluasi sebelum berikan perpanjangan ataupun pembaruan Hak Pakai. Terlepas dari tahapan evaluasi itu, penguasaan tanah dengan Hak Pakai oleh orang asing dalam jangka waktu sangat lama berpotensi berbenturan dengan Hak Bangsa. Dengan jangka waktu Hak Pakai yang selama itu dan secara turun temurun, hal tersebut sama saja dengan kembali ke masa Hindia-Belanda. Selain itu, PP No. 40/1996 merupakan pengaturan khusus terhadap Hak Pakai. Jadi sudah selayaknya jika menjadikan PP No. 40/1996 sebagai rujukan dalam pemberian Hak Pakai. Akan tetapi, pemberian jangka waktu lebih lama tersebut menyiratkan bahwa Pemerintah lebih mengedepankan dan menguntungkan kepentingan pihak asing ketimbang kebutuhan Hak Pakai untuk subjek dalam negeri.

Adanya anggapan bahwa PP Hunian Orang Asing merupakan lex specialis dari PP No. 40 Tahun 1996 yang merupakan lex generalis. Dalam asas lex specialis derogat legi generalis tersebut menyatakan bahwa hukum yang lebih khusus mengenyampingkan hukum yang lebih umum. Akan tetapi asas tersebut tidak dapat dipakai sembarangan. Dalam menggunakan asas tersebut, sebelumnya terdapat dua kriteria yang harus dipenuhi yaitu (1) merupakan produk hukum yang setara; dan (2) produk hukum tersebut berada dalam satu rezim hukum yang sama. Kedua regulasi tersebut berbentuk PP yang sederajat, akan tetapi keduanya berada dalam rezim hukum yang berbeda. PP No. 40/1996 tunduk kepada hukum tanah, sedangkan PP Hunian Orang Asing tunduk kepada hukum perhutangan yang mengatur penguasaa hak atas benda bukan tanah. Van Dijk mengatakan bahwa hukum perhutangan bukan dimaksud sebagai hukum hutang piutang, tapi sebagai hukum yang mengatur tentang penguasaan atas benda bukan tanah serta peralihan dan hukum jasa-jasa. ${ }^{10} \mathrm{Hal}$ ini adalah konsekuensi dari dianutnya Asas Pemisahan Horizontal yang bersumber dari Hukum Adat dalam hukum tanah nasional. Maka dari itu penggunaan asas lex specialis derogat legi generalis kurang tepat.

PP Hunian Orang Asing menentukan bahwa pemilikan rumah tunggal sebagai tempat tinggal orang asing yang berkedudukan di Indonesia berdasarkan atas Hak Pakai terhadap rumah tunggal diatas Hak Pakai di atas tanah negara atau Hak Pengelolaan atau Hak Pakai di atas Hak Milik yang dikuasai berdasarkan perjanjian pemberian. Kedudukan orang asing yang berkedudukan di Indonesia sebagai subjek Hak Pakai dalam PP Hunian Orang Asing tersebut sudah sesuai dengan orang asing yang berkedudukan di Indonesia yang dimaksud dalam PP No. 40 Tahun 1996, yaitu orang asing yang kehadirannya di Indonesia memberikan manfaat bagi pembangunan nasional, seperti yang dijelaskan sebelumnya.

${ }^{10}$ Van Dijk, Dalam Eman Ramelan, "Asas Pemisahan Horizontal dalam Hukum Tanah Nasional", Pidato Pengukuhan Guru Besar Ilmu Hukum Agraria Universitas Airlangga, 13 Desember 2008. 
Dalam Asas Pemisahan Horizontal, pada prinsipnya pemilikan bangunan terpisah dengan penguasaan tanahnya, kecuali jika menurut kenyataan pemilikan bangunan dan penguasaan hak atas tanahnya berada pada satu orang. Alhasil, kepemilikan atas tanah tidak dengan sendirinya meliputi bangunan dan tanaman yang ada di atasnya. Dengan demikian, perbuatan hukum mengenai tanah tidak dengan sendirinya meliputi pula bangunan dan tanaman yang ada di atasnya, ${ }^{11}$ begitupun pula sebaliknya. Dengan kata lain, ketika bangunan dimiliki oleh orang asing dengan status Hak Pakai, maka tanah di bawahnya bukan otomatis menjadi miliknya juga. Penggunaan Asas Pemisahan Horizontal tersebut akan berbeda jika rumah tunggal orang asing yang berkedudukan di Indonesia tersebut dibangun di atas Hak Pakai di atas Hak Milik yang dikuasai dengan perjanjian dengan WNI, terutama yang memiliki hubungan keluarga dengan orang asing. Hal ini dikarenakan akan adanya hubungan antara orang asing dengan Hak Milik, maka hal ini perlu diwaspadai dan tidak dapat dipertanggungjawabkan secara yuridis karena memiliki kecenderungan untuk melanggar Pasal 26 ayat (2) UUPA yaitu memindahkan Hak Milik kepada orang asing. Dengan kata lain, penyelundupan hukum. ${ }^{12}$

Maria S.W. Sumardjono memberikan beberapa indikasi adanya pemindahan hak terselubung, yaitu ${ }^{13}$ (1) uang sewa dibayar sekaligus atau uang pengganti untuk menyerahkan Hak Pakai besarnya kurang lebih sama dengan harga tanah tersebut; (2) jangka waktu perjanjian melampaui batas kewajaran; (3) pemilik hanya dapat meminta kembali tanahnya dengan membayar kembali sebesar harga tanah yang sebenarnya; (4) menjual rumah atau bangunan di atas Hak Milik, tetapi tanahnya diserahkan dengan Hak Pakai atau hak sewa. Ketentuan PP Hunian Orang Asing memberikan kesempatan kepada orang asing yang berkedudukan di Indonesia untuk memiliki Hak Pakai terhadap rumah tunggal di atas tanah Hak Pakai di atas Hak Milik dengan perjanjian dengan jangka waktu paling lama 80 tahun. Hal tersebut merupakan suatu perjanjian dengan jangka waktu melampaui batas kewajaran dan PP Hunian Orang Asing memberikan kesempatan tersebut. Hal tersebut menunjukkan bahwa secara materil sebenarnya telah terjadi pemindahan Hak Milik kepada orang asing secara terselubung dan merupakan penyelundupan hukum. PP Hunian Orang Asing secara tidak langsung memfasilitasi orang asing yang berkedudukan di Indonesia untuk memiliki Hak Milik dengan dalih Hak Pakai. Hal ini secara nyata merupakan pengingkaran terhadap asas nasionalitas sekaligus Hak Bangsa yang merupakan hak penguasaan tanah tertinggi.

\footnotetext{
11 Urip Santoso, “Hukum Perumahan”, Kencana, Jakarta, (2014): 253.

12 Maria S.W. Sumardjono, "Kebijakan Pertanahan Antara Regulasi dan Implementasi", Kompas, Jakarta, (2009): 163.

13 Ibid. hlm 165.
} 
Perjanjian yang merupakan penyelundupan hukum tersebut tidak dapat berlindung dengan dalih kebebasan berkontrak seperti yang di atur dalam Pasal 1338 BW. Biarpun demikian, kebebasan berkontrak tersebut tidak dapat terjadi jika bertentangan dengan kesusilaan atau dengan ketertiban umum atau adanya suatu sebab yang tidak terlarang dan ada itikad baik. ${ }^{14} \mathrm{Hal}$ ini secara tegas terdapat dalam Pasal 1320 ayat (4) Jo. Pasal 1337 BW. Lebih lanjut, Subekti mengemukakan bahwa perjanjian yang dibuat antara WNI dengan orang asing yang didasarkan pada causa palsu, yakni perjanjian yang dibuat dengan pura-pura, untuk menyembunyikan causa yang sebenarnya tidak diperbolehkan. Dalam hal ini, perjanjian tersebut dianggap sudah batal sejak semula dan hakim berwenang, karena jabatannya, mengucapkan pembatalan itu, walaupun tidak diminta oleh sesuatu pihak (batal secara mutlak). ${ }^{15}$ Selain itu, Subekti juga menjelaskan bahwa tidak semua perjanjian yang dibuat mempunyai kekuatan mengikat sebagai undang-undang. Hanya perjanjian yang dibuat secara sah, yang mengikat kedua belah pihak. ${ }^{16}$

Selain dapat memiliki rumah tunggal dengan status Hak Pakai, orang asing yang berkedudukan di Indonesia juga memiliki pilihan untuk memiliki Sarusun dengan status HMSRS yang bersifat perseorangan yang terpisah dengan hak bersama atas bagian bersama, benda bersama, dan tanah bersama. Adanya HMSRS bukan dalam artian pemilik dapat memiliki Sarusun tersebut selama-lamanya, tetapi bergantung kepada status hak atas tanahnya. PP Hunian Orang Asing menetapkan Sarusun yang dapat dimiliki oleh orang asing yang berkedudukan di Indonesia dibangun di atas tanah Hak Pakai atas tanah negara atau tanah pengelolaan dengan jangka waktu paling lama 25 tahun dan dapat diperpanjang untuk jangka waktu paling lama 20 tahun dan dipembaruan paling lama selama 25 tahun. Ketentuan ini juga berarti orang asing yang memiliki HMSRS bukan otomatis memiliki tanah dengan status Hak Milik. Hal ini disebabkan karena Asas Pemisahan Horizontal yang dianut oleh hukum tanah nasional dan karakteristik dari tanah Rusun yang berstatus tanah bersama.

\section{Perbandingan Hukum Pemilikan Tanah dan Bangunan oleh Orang Asing antara Indonesia dengan Singapura dan Vietnam.}

Perbandingan hukum terkait pemilikan tanah dan bangunan oleh orang asing antara Indonesia dengan dua negara, yaitu Singapura dan Vietnam. Pemilihan Singapura dan Vietnam sebagai negara pembanding dilakukan karena beberapa alasan. Pertama,

\footnotetext{
${ }^{14}$ I Kadek Ari Sucitha, "Tinjauan Yuridis Akta Kuasa Menjual dalam Penjualan Tanah dan Bangunan oleh Warga Negara Asing di Kabupateng Badung", Tesis Program Magister Kenotariatan di Fakultas Hukum Universitas Hasanuddin, Tidak Diterbitkan, (2012): 56.

15 Maria S.W. Sumardjono, "Alternatif Kebijakan Pengaturan Hak Atas Tanah Beserta Bangunan bagi Warga Negara Asing dan Badan Hukum Asing", Kompas, Jakarta, (2008) : 19.

16 Ibid. hlm. 139.
} 
kesamaan letak geografis antara Indonesia dan dua negara lainnya terletak di kawasan Asia Tenggara, bersama lima negara lainnya. Selain memiliki letak wilayah yang saling berdekatan, ketiga negara juga bergabung dalam Association of South East Asian Nations (selanjutnya disingkat ASEAN) yang merupakan organisasi geopolitik dari negara-negara yang berada di wilayah Asia Tenggara.

Tabel 2: Peringkat Negara-negara Asia Tenggara dalam Ease of Doing Bussiness 2014-2018

\begin{tabular}{llllll}
\hline \multirow{2}{*}{ Negara } & \multicolumn{5}{c}{ Peringkat di Tahun } \\
\cline { 2 - 6 } & $\mathbf{2 0 1 4}$ & $\mathbf{2 0 1 5}$ & $\mathbf{2 0 1 6}$ & $\mathbf{2 0 1 7}$ & $\mathbf{2 0 1 8}$ \\
\hline Brunei Darusslam & 59 & 101 & 84 & 72 & 56 \\
\hline Filipina & 108 & 95 & 103 & 99 & 113 \\
\hline Indonesia & 120 & 114 & 109 & 91 & 72 \\
\hline Kamboja & 137 & 135 & 127 & 131 & 135 \\
\hline Laos & 159 & 148 & 134 & 139 & 141 \\
\hline Malaysia & 6 & 18 & 18 & 23 & 24 \\
\hline Myanmar & 182 & 177 & 167 & 170 & 171 \\
\hline Singapura & 1 & 1 & 1 & 2 & 2 \\
\hline Thailand & 18 & 26 & 49 & 46 & 26 \\
\hline Vietnam & 99 & 78 & 90 & 82 & 68 \\
\hline Sumber:Bahan & $130 n h 4 k u m, ~$ & & & & \\
\hline
\end{tabular}

Sumber: Bahan nonhukum, diolah tahun 2018

Kedua, kemudahan berinvestasi. Ease of Doing Bussiness merupakan salah satu indeks yang dikeluarkan oleh Bank Dunia untuk mengukur tingkat kemudahan berinvestasi di suatu negara. Dalam memberikan peringkat, Ease of Doing Bussiness mempunyai beberapa indikator, salah satunya adalah registering property atau pendaftaran properti. Selain registering property, indikator lain yang digunakan oleh Bank Dunia adalah starting a business, dealing with construction permits, getting electricity, getting credit, protecting minority investors, paying taxes, trading across borders, enforcing contracts dan resolving insolvency. Berikut adalah peringkat negara-negara di kawasan Asia Tenggara dalam Ease of Doing Bussiness dalam kurun waktu 2012 2015; 
Tabel 3: Perbandingan Subyek Hukum Pengaturan Hak atas Tanah dan Bangunan Bagi Pihak Asing di Indonesia, Singapura dan Vietnam

\begin{tabular}{|c|c|c|}
\hline \multicolumn{3}{|c|}{ Negara } \\
\hline Indonesia $^{17}$ & Singapura ${ }^{18}$ & Vietnam $^{19}$ \\
\hline Orang & Orang Asing adalah: & Orang Asing: \\
\hline $\begin{array}{l}\text { Berkedudukan di Indonesia } \\
\text { adalah: }\end{array}$ & $\begin{array}{l}\text { 1. Warga Negara Asing } \\
\text { (foreign person) }\end{array}$ & $\begin{array}{l}\text { 1. Warga Negara Asing } \\
\text { (foreign individual) }\end{array}$ \\
\hline $\begin{array}{l}\text { 1. Bukan WNI. } \\
\text { 2. Keberadaanya memberikan } \\
\text { manfaat, melakukan usaha, } \\
\text { bekerja, atau berinvestasi } \\
\text { di Indonesia. }\end{array}$ & $\begin{array}{l}\text { 2. Badan hukum asing } \\
\text { (foreign company) }\end{array}$ & $\begin{array}{l}\text { 2. Badan Hukum Asing } \\
\text { (foreign company) }\end{array}$ \\
\hline
\end{tabular}

Berdasarkan tabel 3, dapat dilihat jika subjek pihak asing di setiap negara berbeda. Di Singapura, pihak asing yang dapat memiliki tanah ataupun bangunan mencakup WNA (foreign person) dan badan hukum asing (foreign company). Menurut ketentuan Singapura yang dimaksud Warga Negara Asing (foreign person) adalah:

a. Bukan WN Singapura;

b. Memperoleh status sebagai permanent resident (berkedudukan tetap);

c. Memberi manfaat ekonomi ke Singapura atau yang mampu kontribusi ekonomi ke Singapura; atau

d. Memiliki kualifikasi profesional atau lainnya atau pengalaman yang memiliki nilai atau manfaat ke Singapura.

Badan hukum asing (foreign company) menurut ketentuan Singapura adalah:

a. Perusahaan, badan hukum, perkum-pulan atau badan-badan lain yang didirikan di luar Singapura;

17 UU No. 5 Tahun 1960 tentang Peraturan Dasar Pokok-pokok Agraria Jo. PP No. 103 Tahun 2015 tentang Pemilikan Rumah Tempat Tinggal atau Hunian oleh Orang Asing yang Berkedudu-kan di Indonesia Jo. Pernenatr No. 13 Tahun 2016 tentang Tata Cara Pemberian, Pelepasan atau Pengalihan Hak atas Pemilikan Rumah Tempat Tinggal atau Hunian oleh Orang Asing yang Berkedudukan di Indonesia.

${ }_{18}$ Maria S.W. Sumardjono, "Alternatif Kebijakan Pengaturan Hak Atas Tanah Beserta Bangunan bagi Warga Negara Asing dan Badan Hukum Asing", Kompas, Jakarta, 2008, hlm. 72 - 77 dan the Singapore Land Titles Act 1993 Jo. the Singapore Residential Property Act 1976.

19 the Vietnam Land Law No. 45/2013/QH13 Jo. the Vietnam Law on Housing No. 65/2014/QH13 Jo. the Vietnam Law on Real Estate Business No. 66/2014/QH13. 
b. Badan hukum yang didirikan di Singapura dengan sebagian atau seluruh anggota atau direkturnya bukan WN Singapura;

c. Perkumpulan atau badan-badan lain yang menurut hukum negara asalnya dapat dituntut atau menuntut atau me-miliki tanah atas nama sekretaris atau pimpinan badan atau perkumpulan tersebut yang sebagian atau seluruh anggota atau direkturnya bukan WN Singapura.

Hal serupa juga di atur dalam peraturan perundang-undangan Vietnam. Orang Asing dalam ketentuan Hukum Vietnam adalah (1) Warga Negara Asing; (2) Badan Hukum Asing. Warga Negara Asing (foreign individual) menurut ketentuan hukum Vietnam adalah:

1. WNA yang memiliki investasi langsung di Vietnam atau memegang posisi manajemen di perusahaan yang beroperasi di Vietnam; atau

2. WNA yang telah membuat kontribusi ke Vietnam dan kontribusi tersebut telah diakui oleh Presiden atau Perdana Menteri Vietnam; atau

3. WNA yang memiliki gelar universitas atau tingkat pendidikan yang lebih tinggi dan bekerja di bidang sosial-ekonomi, dan mereka yang memiliki pengetahuan khusus yang diperlukan Vietnam; atau

4. WNA yang menikah dengan Warga Negara Vietnam;

Badan Hukum Asing (foreign company) menurut ketentuan hukum Vietnam adalah: Perusahaan yang berinvestasi dan beroperasi di Vietnam, yang bukan perusahaan real estate, dan memiliki permintaan akomodasi perumahan bagi karyawannya.

Berbeda dari kedua negara, Indonesia pihak asing hanyalah orang asing yang berkedudukan di Indonesia yang didefinisikan sebagai orang yang bukan WNI yang keberadaanya memberikan manfaat, melakukan usaha, bekerja, atau berinvestasi di Indonesia. Berdasarkan perbandingan tersebut, untuk badan hukum asing, Singapura lebih memiliki kriteria yang luas. Berdasarkan subjek hukum pihak asing yang di atur oleh ketiga negara, dapat dilihat jika faktor ekonomi menjadi indikator penting diberikannya hunian kepada orang asing ataupun badan hukum asing.

Substansi pembanding kedua adalah berkaitan dengan: (a) status obyek sebagai Hunian dan Bukan Hunian; (b) Jangka Waktu; (c) Pembatasan unit; (d) Pembatasan kuota; (e) Pembatasan Harga; (f) Zonasi dan (g) Status Tanah dan Bangunan.

Perbandingan pengaturan berdasarkan hukum Indonesia, Singapura dan Vietnam, berkaitan obyek pengaturan hukum hak atas tanah warga Negara asing, memiliki beberapa persamaan dan perbendaan. Perbandingan yang dimaksud objek yang mencakup hunian dan bukan hunian. Berdasarkan obyek pengaturan, terdapat persamaan baik di Indonesia maupun Singapura dan Vietnam membuat pengaturan 
yang berbeda bagi jenis hunian, namun terdapat perbedaan yaitu untuk Indonesia perbedaan pengaturan berdasarkan jenis bangunannya apakah rumah tunggal atau rumah susun. Sedangkan Singapura dan Vietnam membuat klasifikasi pengaturan berdasarkan peruntukan/penggunaan bangunan.

Tabel 4 : Perbandingan Obyek Hukum Pengaturan Hak atas Tanah dan Bangunan Bagi Pihak Asing di Indonesia, Singapura dan Vietnam

\begin{tabular}{|c|c|c|c|}
\hline \multirow{2}{*}{$\begin{array}{l}\text { Perbandingan } \\
\text { Obyek }\end{array}$} & \multicolumn{3}{|c|}{ NEGARA } \\
\hline & Indonesia & Singapura & Vietnam \\
\hline $\begin{array}{l}\text { a. Hunian dan } \\
\text { Bukan Hunian }\end{array}$ & $\begin{array}{l}\text { 1. Rumah tunggal } \\
\text { yang dibangun di } \\
\text { atas Hak Pakai, } \\
\text { Hak Pengelolaan } \\
\text { atau Hak Pakai di } \\
\text { atas Hak Milik. } \\
\text { 2. Satuan rumah } \\
\text { susun yang } \\
\text { dibangun di atas } \\
\text { Hak Pakai atau } \\
\text { Hak Pengelolaan. }\end{array}$ & $\begin{array}{l}\text { Hunian dan bukan } \\
\text { hunian yang } \\
\text { membutuhkan } \\
\text { persetujuan } \\
\text { pejabat yang } \\
\text { berwenang }\end{array}$ & $\begin{array}{l}\text { 1. Rumah tunggal } \\
\text { untuk ditinggali } \\
\text { sendiri } \\
\text { 2. Rumah tunggal } \\
\text { bagi karyawan } \\
\text { perusahaan } \\
\text { asing } \\
\text { 3. Apartemen } \\
\text { untuk ditinggali } \\
\text { sendiri } \\
\text { 4. Apartemen bagi } \\
\text { karyawan } \\
\text { perusahaan } \\
\text { asing }\end{array}$ \\
\hline b. Jangka Waktu & $\begin{array}{l}\text { 1. Diberikan } \\
\text { pertama kali } \\
\text { untuk jangka } \\
\text { waktu } 30 \text { tahun. } \\
\text { 2. Dapat } \\
\text { diperpanjang } \\
\text { untuk jangka } \\
\text { waktu } 20 \text { tahun. } \\
\text { 3. Dapat diperbarui } \\
\text { untuk jangka } \\
\text { waktu } 30 \text { tahun. }\end{array}$ & $\begin{array}{l}\text { Diberikan untuk } \\
\text { jangka waktu } 99 \\
\text { tahun, namun } \\
\text { beberapa } \\
\text { bangunan } \\
\text { diberikan dalam } \\
\text { jangka waktu yang } \\
\text { lebih singkat. } \\
\text { Misalnya Leasehold } \\
\text { estate. }\end{array}$ & $\begin{array}{l}\text { 1. Diberikan } \\
\text { pertama kali } \\
\text { untuk jangka } \\
\text { waktu } 50 \text { tahun. } \\
\text { 2. Dapat } \\
\text { diperpanjang } \\
\text { untuk jangka } \\
\text { waktu } 50 \text { tahun. } \\
\text { (Khusus badan } \\
\text { hukum asing } \\
\text { harus } \\
\text { dicatatkan } \\
\text { dalam sertifikat } \\
\text { investasi) }\end{array}$ \\
\hline
\end{tabular}




\begin{tabular}{llll}
\hline $\begin{array}{l}\text { c. Pembatasan } \\
\text { Unit }\end{array}$ & 1 unit & Tidak diatur & 1 unit \\
\hline $\begin{array}{l}\text { d. Pembatasan } \\
\text { Kuota }\end{array}$ & Tidak diatur & Tidak diatur & Diatur \\
\hline $\begin{array}{l}\text { e. Pembatasan } \\
\text { Harga }\end{array}$ & $\begin{array}{l}\text { Mengacu kepada } \\
\text { harga tanah dan } \\
\text { pasaran tertinggi di }\end{array}$ & Diserahkan kepada & Pemerintah \\
& setiap wilayah. & & menentukan harga \\
& Tidak diatur & Diatur & \\
\hline f. Zonasi & Terpisah (Horizontal & Bersatu (Accessie & Terpisah \\
\hline $\begin{array}{l}\text { g. Status tanah } \\
\text { dan } \\
\text { bangunan }\end{array}$ & Scheiding) & Beginsel) & (Horizontal \\
& & & Scheiding) \\
\hline
\end{tabular}

Di Indonesia objek yang dapat dimiliki oleh orang asing berupa rumah tunggal dengan status Hak Pakai atau Sarusun dengan status HMSRS. Dengan kata lain orang asing tidak dapat memiliki tanah. Hal ini merupakan dengan dianutnya Asas Pemisahan Horizontal dalam hukum tanah nasional Indonesia. Rumah tunggal dan Sarusun dibatasi hanya satu unit untuk setiap orang asing yang berkedudukan di Indonesia. Jangka waktu pemilikan rumah tunggal tersebut diberikan pertama kali untuk jangka waktu 30 tahun yang dapat diperpanjang untuk jangka waktu 20 tahun serta dapat diperbarui untuk jangka waktu 30 tahun. Hal ini berarti jangka waktu yang diberikan maksimal selama 80 tahun. Adapun Sarusun dimiliki dengan status HMSRS yang jangka waktunya mengukuti jangka waktu tanah tempat Rusun tersebut dibangun. Diadakan pula pembatasan harga minimal yang mengacu kepada harga tanah dan pasaran tertinggi di setiap wilayah. Selain itu, rumah tunggal dan Sarusun dapat diwariskan dengan ketentuan-ketentuan yang sudah ditetapkan. Sedangkan untuk jual-beli ataupun sewa menyewa terhadap rumah tunggal atau Sarusun yang dimiliki oleh orang asing tidak di atur dalam peraturan perundang-undangan Indonesia. Bukan hanya itu, batasan kuota rumah tunggal atau hunian yang dapat dimiliki orang asing beserta zonasinya tidak di atur dalam peraturan perundang-undangan.

Kepemilikan hunian di Singapura, objeknya lebih variatif dari pada di Indonesia yang mencakup :

a. tanah kosong untuk hunian;

b. properti yang berdiri sendiri; 
c. landed property dalam pembangunan rumah susun yang tidak termasuk dalam pembangunan kondominium yang disetujui sesuai Planning Act;

d. rumah toko yang didirikan dalam wilayah yang diperuntukkan bagi hunian;

e. seluruh apartemen atau seluruh unit dalam kondominium;

f. leasehold estate yang termasuk dalam restricted residential property untuk jangka waktu tidak lebih dari 7 tahun, termasuk perpanjangannya;

g. flat HDB yang dibeli langsung dari HDB;

h. Flat HDB yang dijual kembali sesuai dengan persetujuan HDB;

i. rumah toko HDB;

j. kondominium eksekutif yang dibeli sesuai dengan the Executive Condominium Housing Scheme Act 1996.

Singapura menggunakan Asas Perlekatan dalam hukum tanah nasionalnya yang berimplikasi pada kepemilikan bangunan dan tanah oleh orang asing menjadi satu kesatuan.

Jangka waktu pemberian hak atas tanah terdapat mekanisme yang sama antara Indonesia dan Vietnam, yaitu dengan skema pembatasan jangka waktu untuk pemberian hak pertama kali dan selanjutnya ditentukan waktu perpanjangan. Sedangkan Singapura pemberian hak hanya diberikan tanpa mekanisme perpanjangan, namun masa berlakunya panjang dan ada ketentuan khusus bagi Leasehold estate. Jangka waktu kepemilikan properti di Singapura mencapai 99 tahun dan hal itu dilakukan tanpa perpanjangan. Selain itu, Singapura juga di tidak mengatur batasan unit ataupun kuota bangunan untuk orang asing dan badan hukum asing. Adapun untuk harga tanah ataupun bangunan disertahkan kepada mekanisme pasar. Biarpun demikian, Singapura memiliki zonasi untuk bangunan-bangunannya. Perbedaan berkaitan ketentuan kuota, baik Indonesia maupun singapura tidak mengatur khusus, namun Vietnam membuat ketentuan khusus, yaitu:

a. Pihak asing dapat memiliki hingga $10 \%$ unit rumah tunggal dan dalam satu wilayah WNA dapat memiliki 250 unit serta badan hukum asing tidak boleh melebihi 2.500 unit

b. Pihak asing dapat memiliki hingga 30\% unit apartemen dalam satu gedung apartemen dan dalam satu wilayah tidak lebih dari $30 \%$ dari total unit semua bangunan apartemen

Penentuan harga tanah di Negara Vietnam, pemerintah menentukan harga yang berdasarkan nilai sebenarnya dari tanah dalam keadaan normal. Jika ada perbedaan besar antara perhitungan mereka dibandingkan dengan harga pasar. Ketentuan 
Negara Vietnam, objek yang dapat dimiliki oleh orang asing dan badan hukum hampir serupa dengan Indonesia, yaitu rumah tunggal dan apartemen atau Sarusun. Akan tetapi rumah dan apartemen tersebut juga diperuntukkan bagi tempat tinggal karyawan badan hukum asing yang memenuhi kriteria. Jangka waktu pemilikan properti pertama kali diberikan selama 50 tahun dan dapat diperpanjang 50 tahun. Biarpun demikian, karena Vietnam menganut Asas Pemisahan Horizontal, maka biarpun memiliki bangunan dengan jangka waktu yang lama, orang asing tersebut bukan berarti memiliki tanah di Vietnam. Ketentuan ini merupakan pengejawantahan dari Pasal 1 the Vietnam Land Law No. 45/2013/QH13 yang menyatakan bahwa seluruh tanah di Vietnam adalah milik rakyat Vietnam dan Pemerintah sebagai perwujudan dari rakyat memiliki hak atas itu. Hal ini berarti seluruh tanah di Vietnam adalah milik pemerintah sehingga tidak dikenal adanya kepemilikan pribadi. Hal ini adalah konsekuensi dari dianutnya paham sosialis oleh Vietnam.

Meskipun memiliki jangka waktu yang sangat lama, orang asing dan badan hukum asing hanya diperbolehkan memiliki satu unit objek. Bukan hanya itu, orang asing dan badan hukum asing dapat memiliki hingga 30\% unit apartemen dalam satu gedung apartemen dan dalam satu wilayah tidak lebih dari $30 \%$ dari total unit semua bangunan apartemen. Selain itu, orang asing dan badan hukum asing dapat memiliki hingga $10 \%$ unit rumah tunggal dan dalam satu wilayah WNA dapat memiliki 250 unit serta badan hukum asing tidak boleh melebihi 2.500 unit. Harga objek tersebut ditentukan oleh Pemerintah berdasarkan nilai sebenarnya dari tanah dalam keadaan normal. Jika ada perbedaan besar antara perhitungan mereka dibandingkan dengan harga pasar. Selain itu Pemerintah juga menerapkan zonasi terhadap rumah tunggal ataupun apartemen.

Substansi pembanding ketiga adalah perbuatan atau peristiwa hukum terhadap objek yang dapat di haki oleh asing. Indonesia tidak mengatur persoalan jual beli objek yang dapat di haki, berbeda dengan Singapura dan Vietnam yang mengatur perbuatan hukum ini. Selain jual beli, Indonesia juga tidak mengatur persoalan sewa menyewa objek yang dapat di haki oleh orang asing. Sedangkan di Singapura, hal ini dikenakan pajak hingga 15\%. Hal ini juga diatur di Vietnam, akan tetapi penulis tidak mendapatkan perinciannya.

Tabel: 5 Perbandingan Peristiwa Hukum Pengaturan Hak atas Tanah dan Bangunan Bagi Pihak Asing di Indonesia, Singapura dan Vietnam

\begin{tabular}{llll}
\hline Peristiwa Hukum & Indonesia & Singapura & Vietnam \\
\hline a. Jual-Beli & Tidak diatur & Diatur & Diatur \\
\hline b. Sewa-menyewa & Tidak diatur & $\begin{array}{l}\text { Dikenai pajak 15 } \\
\text { persen. }\end{array}$ & Diatur \\
& & & \\
\hline
\end{tabular}




\begin{tabular}{llll}
\hline c. Pewarisan & Diatur & Diatur & Diatur \\
\hline
\end{tabular}

Pewarisan adalah peristiwa hukum yang di atur di Indonesia. Apabila ahli waris adalah orang asing, maka ia harus mempunyai izin tinggal di Indonesia. Jika ahli waris sudah tidak memenuhi syarat pemegang hak, maka dalam jangka waktu 1 tahun wajib melepaskan atau mengalihkan hak atas rumah dan tanahnya kepada pihak lain yang memenuhi syarat. Apabila belum dilepaskan maka tanah tersebut akan dilelang oleh negara jika dibangun di atas Hak Pakai atas tanah negara atau menjadi milik pemegang Hak Milik atau Hak Pengelolaan, jika rumah tersebut dibangun diatas tanah berdasarkan perjanjian.

Pewarisan juga di atur di Singapura. Apabila orang asing yang memperoleh landed residential property sebagai warisan harus memperoleh persetujuan pejabat yang berwenang. Jika tidak diperoleh persetujuan pejabat, dalam kurun waktu 10 tahun setelah tanggal kematian, properti tersebut harus dijual kepada WN Singapura atau WNA yang memperoleh persetujuan pejabat yang berwenang. Hasil penjualan diserahkan kepada pihak yang berhak menerimanya. Hal ini juga diatur di Vietnam, akan tetapi penulis tidak mendapatkan perinciannya.

Tabel 6 : Sanksi dan Pengawasan

\begin{tabular}{llll}
\hline Perbandingan & Indonesia & Singapura & Vietnam \\
\hline Sanksi & diatur & diatur & $\begin{array}{l}\text { Informasi tidak } \\
\text { ditemukan. }\end{array}$ \\
& & & \\
\hline Instansi & Tidak diatur & 1. Controller of & 1. The Ministry of \\
Pengawas & & Residential Property & Defence \\
& & Land Dealing & 2. The Ministry of Public \\
& 2. Minister for Law & Security \\
\hline
\end{tabular}

Sanksi adalah pembanding keempat. Di Indonesia, apabila ada perjanjian yang menggunakan nama WNI sebagai trustee atau nominee adalah batal demi hukum dan tanahnya menjadi milik negara. Selain itu, semua pembayaran yang telah diterima oleh pemilik tidak dapat dituntut kembali. Hal ini juga diatur di Singapura. Jika persetujuan pejabat diberikan untuk pembelian landed residential property, properti tersebut harus dihuni sendir dan tidak disewakan. Pelanggaran terhadap hal tersebut dikenai denda 5.000 SGD atau 3 Tahun pidana atau pidana dan denda. Selain itu, jika perjanjian yang menggunakan nama WN Singapura sebagai trustee atau nominee adalah batal demi hukum. Semua pembayaran yang telah dikeluarkan oleh WNA tidak dapat dituntut kembali. Selian itu, pemberian atau hibah landed residential property dari seorang WN 
Singapura kepada WNA adalah batal demi hukum. Untuk Vietnam, penulis tidak mendapatkan informasi tentang ini.

Pembanding terakhir adalah instansi yang mengawasi objek yang dapat di haki oleh asing. Indonesia tidak mengatur tentang instansi ini. Hal ini berbeda dengan Singapura yang memberikan kewenangan pengawasan kepada Controller of Residential Property Land Dealing dan Minister for Law. Adapun Vietnam memberikan kewenangan pengawasannya kepada The Ministry of Defense dan The Ministry of Public Security.

Dari perbandingan antar Indonesia, Singapura dan Vietnam dapat dilihat jika pengaturan Indonesia terhadap pemilikan hunian oleh orang asing masih belum selengkap Singapura ataupun Vietnam. Banyak pengaturan-pengaturan yang dapat diadopsi dalam pengaturan Indonesia akan tetapi ha; tersebut tentunya harus dikaji lebih mendalam dan dikaitkan dengan asas-asas fundamental dalam UUPA sehingga tidak mencederai asas nasionalitas ataupun Hak Bangsa yang merupakan ciri khas Indonesia.

\section{CONCLUSION}

Orang asing yang berkedudukan di Indonesia tidak dapat memiliki tanah meskipun telah memiliki bangunan di atasnya. Hal ini karena dianutnya Asas Pemisahan Horizontal dalam hukum tanah nasional yang tidak memungkinkan orang asing untuk memiliki tanah meskipun telah memiliki bangunan di atasnya. Meskipun demikian, jangka waktu Hak Pakai yang terlampau lama hingga mencapai 80 tahun dapat berbenturan dengan Hak Bangsa.

Pembatasan penguasaan tanah oleh orang asing yang berkedudukan di Indonesia merupakan kewajiban bagi pemerintah dalam menghormati dan melindungi Hak Bangsa sebagai hak penguasaan atas tanah yang tertinggi. Perbandingan pembatasan penguasaan tanah oleh orang asing yang berkedudukan di Indonesia di dapat melalui perbandingan terhadap Singapura dan Vietnam. Pembatasan penguasaan tanah tersebut dilakukan dengan melakukan pembatasan pemilikan rumah tempat tinggal dalam hal 1) penjabaran subjek; 2) pembatasan kuota; 3) zonasi; 4) pengaturan terkait jual-beli; 5) pengaturan terkait sewa-menyewa; serta 6) pembentukan tugas pengawasan pemilikan rumah tempat tinggal bagi orang asing yang berkedudukan di Indonesia. 


\section{REFERENCES}

Buku

A.P. Parlindungan, 1991, Landreform di Indonesia Suatu Studi Perbandingan, Mandar Maju, Bandung, 1991.

Efendi Perangin, 401 Pertanyaan dan Jawaban Tentang Hukum Agraria, Raja Grafindo Persada, Jakarta, 1994.

Maria S.W. Sumardjono, Alternatif Kebijakan Pengaturan Hak Atas Tanah Beserta Bangunan bagi Warga Negara Asing dan Badan Hukum Asing, Kompas, Jakarta, 2008.

Maria S.W. Sumardjono, Kebijakan Pertanahan Antara Regulasi dan Implementasi, Kompas, Jakarta, 2009.

Mohammad Hatta, Hukum Tanah Nasional Dalam Perspektif Negara Kesatuan, Media Abadi, Yogyakarta, 2005.

Muhammad Ilham Arisaputra, Reforma Agraria di Indonesia, Sinar Grafika, Jakarta, 2015.

Urip Santoso, Hukum Perumahan, Kencana, Jakarta, 2014.

\section{Peraturan Perundang-Undangan Republik Indonesia}

Undang-Undang Nomor 5 Tahun 1960 tentang Peraturan Dasar Pokok-pokok Agraria.

Undang-Undang Nomor 20 Tahun 2008 tentang Usaha Mikro, Kecil dan Menengah.

Peraturan Pemerintah Nomor 103 Tahun 2015 tentang Pemilikan Rumah Tempat Tinggal atau Hunian Bagi Orang Asing yang Berkedudukan di Indonesia.

Peraturan Menteri Agraria dan Tata Ruang/Kepala Badan Pertanahan Nasional Nomor 13 Tahun 2016 tentang Tata Cara Pemberian, Pelepasan atau Pengalihan Hak atas Pemilikan Rumah Tempat Tingga atau Hunian oleh Orang Asing yang Berkedudukan di Indonesia.

\section{Peraturan Perundang-Undangan Negara Lain}

the Singapore Residential Property Act 1976.

the Singapore Land Titles Act 1993

the Vietnam Land Law No. 45/2013/QH13

the Vietnam Law on Housing No. 65/2014/QH13 
the Vietnam Law on Real Estate Business No. 66/2014/QH13.

\section{Skripsi/Tesis/Desetasi/Pidato}

Eman Ramelan, Asas Pemisahan Horizontal dalam Hukum Tanah Nasional, Pidato Pengukuhan Guru Besar Ilmu Hukum Agraria Universitas Airlangga, 13 Desember 2008.

I Kadek Ari Sucitha, Tinjauan Yuridis Akta Kuasa Menjual dalam Penjualan Tanah dan Bangunan oleh Warga Negara Asing di Kabupateng Badung. Tesis Program Magister Kenotariatan di Fakultas Hukum Universitas Hasanuddin, Tidak Diterbitkan, 2012.

Riyad Febrian Anwar, Aturan Pergerakan Bebas barang Perdagangan Menurut Perspektif the Treaty on the Functioning of European Union 2007 dan the ASEAN Trade in Goods Agreement 2010 (Suatu Kajian Perbandingan), Skripsi Program Ilmu Hukum pada Fakultas Hukum Universitas Hasanuddin, Tidak Diterbitkan, 2015.

\section{Situs Internet}

Eko Adiwaluyo. 2015. Kepemilikan Asing di Properti Nasionalisme Vs Iklim Investasi, diakses dari http://marketeers.com/article/kepemilikan-asing-di-propertinasionalisme-vs-iklim-investasi.html. Diakses pada 1 Agustus 2018.

World Bank, 2015, Indonesia Rising Divide, Diakses dari http://www.worldbank.org/en/news/feature/2015/12/08/indonesia-risingdivide, Diakses pada 1 Agustus 2018.

Organization for Economic Co-operation and Development. 2014. Southeast Asia Investment Policy Derspectives Diakses dari www.oecd.org/daf/inv/investment-policy/Southeast-Asia-Investment-PolicyPerspectives-2014.pdf, Diakses pada 1 Agustus 2018. 